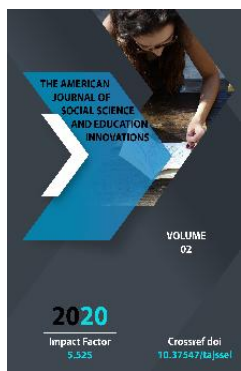

\title{
The Polysemous Terms Related To Mineralogy Used In Alisher Navoi's Works
}

\section{Gulnoza Ernazarova}

Lecturer Of Navoi State Pedagogical Institute, Uzbekistan

Journal Website: http://usajournalshub.c om/index,php/tajssei

\section{ABSTRACT}

This article reveals that the ambiguous terms of mineralogy used in the works of Alisher Navoi which serve an artistic and aesthetic purpose.

\section{KEYWORDS}

Mineralogical term, ambiguity, figurative meaning, methodology, scientific methodology, artisticaesthetic task, metaphor, figurative expression, methodological tool.

\section{INTRODUCTION}

Today, to study linguistic activity of Alisher Navoi from the literary and linguistic point of view is necessary who had given great contribution to the creation of the Uzbek literary language [1].

The scholars such as A.K.Borovkov, A.N.Kononov, A.M.Shcherbak, G. Abdurahmonov, A. Rustamov, E. Fozilov, O. Usmanov, B. Bafoev, K. Eraslan, Ya. Ekmani, who made a great contribution to Navoi studies, and recognize the hard work of linguists such as E.Umarov, B.Hasanov,
M.Rahmatullaeva, A.Karimov, B.Urinbaev, I.Nosirov, Z.Hamidov. The image of Alisher Navoi in children's speech was also mentioned in N.Yarashova's research [2].

In the works of Alisher Navoi, it is noticeable that each word has risen to the level of a poetic symbol. In his poems, even terminological units are assigned an artistic and aesthetic function. And the great word artist demonstrated the possibilities of speech expression of the units of the terminological system of the Uzbek language by using the 
names of precious stones and mineralogical terms in different senses. By assigning new meaning to such units, he demonstrated their lingvopoetic potential.

\section{MATERIALS AND METHODS}

We can see that the lexemes pearl, amber, ruby, pearl, coral, gold, silver, pearlare used in many places in different senses in the works of Alisher Navoi,. These terms, along with the active use in the vernacular, serve to fulfill the artistic and aesthetic function of the poet's poetry.

It is well known that terms are generally monosyllabic units, but polysemous terms are also common in different languages [3]. In particular, the use of mineralogical terms in speech in figurative senses is often observed. In particular, the works of Alisher Navoi note the use of Arabic, Persian-Tajik and other assimilated mineralogical terms in new meanings. We try to justify our opinion through the analysis of some mineralogical terms used in the works of our great poet.

It is known that the word gavhar(pearl )has the following meanings: GAVHAR (PEARL) $(f)$ (Arabic javhar) 1. A precious stone such as a pearl (inju), a pearl (dur), a ruby (yoqut), a diamond (olmos) (Arabic plural jewel) 2. Original (asl), original lineage (asl-nasab), origin (kelibchiqish); 3. The main feature (asosiy xususiyat); 4. Matte r(materiya); 5. Essence (mohiyat), original meaning (asl ma'no), base (tub), basis (asos); Gavhari anjum-star pearl, pearl like stars; Gavhari obdor-the pearl is a pure and clear pearl; figuratively guiding the Pearl of Darkness(Gavhari shahvor) - the Great Pearl; Pearl of the Word (So'z gavhari- Original meaning(asl ma'no), deeply meaningful(chuqur ma'no), meaningful poem(mazmundor she'r); Gavhari shamoyil, gavhar hasab-like pearl quality (gavhar sifat),like pearl(gavha rkabi) [4].

In the following verse by Alisher Navoi, the mineralogical termpearl(gavhar) is used figuratively:

Yog'ib chun toshi yon oshkoro,

Topib ahbob - gavhar, xasm - xoro[5].

Through these verses, Alisher Navoi uses the lexeme of pearl in the deepest sense of the word, describing that when friends find a diamond in stones that are openly poured in all directions, and when enemies encounter a caller.

Continuing his thought, Navoi opened his mouth and said that there were many pearls in it:

Otay deb xora, ganj og'zini ochmay,

Va gar ochib, ne gavharlarki sochmay. ("Farhod and Shirin")

It is understood that the pearl lexeme has risen to the level of a means of figurative expression of thought, along with the decoration of speech.

Tutub gavharlarni yaksar jahonni

Nechukkim xayli axtar osmonni. ("Farhod and Shirin")

In this verse, these pearls are described as occupying the whole world as if the sky were covered with stars.

\section{RESULTS AND DISCUSSIONS}

Alisher Navoi in most places created metaphors on the basis of the mineralogical term "pearl" and managed to narrow down 
the speech, to provide a figurative expression of the idea being expressed:

Yo'q, ul gavharki chun tuproqqa qolg'ay,

Ayog'ostiga chun qolg'ay, usholg'ay.

They are not pearls that will stick to the ground and break underfoot, but pearls that will adorn people's ears when they are rubbed.

Alisher Navoi notes that these gems are not ordinary ornaments worn on the ears, but that these earrings enter the heart and turn it into a treasure:

Aningdek gavharekim jilva chog'i

Muzayyan bo'lg'ay andin el qulog'i,

Durekim quloqni qildi maskan,

Kirib qilg'ay ko'ngul durjini maxzan. ("Farhod and Shirin")

Apparently, Alisher Navoi skillfully used mineralogical terms to describe changes in the human psyche. In his works, mineralogical terms move away from the terminological nature and serve as a methodological tool in the creation of figurative expressions.

In the poet's epic "Farhod and Shirin" there is also the word guharrez, formed on the basis of the word pearl(gavhar). The word means to create(ijod qilmoq), to recite poetry(nazm aytmoq):

Kishi mundoq bo'la olmay guharrez, Magar ulhindu yizodi shakarrez, ("Farhod and Shirin")

No one was able to become a pearl sharer, as in sugar-spreading hinduzoda-Khusrav Dehlaviy.
In Navoi's epic "Farhod and Shirin", along with the lexeme of pearl(gavhar), the term pearl(dur) also served as a methodological tool:

Ko'ngul durjin demay bo'lg'ay labo lab,

Kim u daryoga solg'ay durn to lab,

Kim u gavhardin olsa xalq har dam,

Yuz yilda bo'Imag'ay mingdin biri kam. ("Farhod and Shirin")

In the thought of Alisher Navoi, the sea of the sky is proud of these pearls(durlar)as they lined up the word line:

Takallum rishtasig'a nazmidin dur,

Falak bahriga ul durdin tafoxur, ("Farhod and Shirin")

Alisher Navoi wrote the following lines in the XII chapter of the epic "Hayratul-abror" dedicated to the praise of the Azerbaijani poet Nizami Ganjavi:

Xayli fasohat boshining afsari,

Ganji yaqin afsarining gavhari. ("HayratulAbror")

The poet describes Nizami Ganjavi as the crown of the head of the word artists, the jewel of the crown of innocence.

Navoi also compares the word to a pearl in Chapter XIV of Hayratul-abror, which is devoted to the definition of the word:

So'z guharig'a erur oncha sharaf,

Kim bo'la olmas anga Gavhar sadaf . ("Hayratul-Abror")

In the works of Alisher Navoi we also find such compound words as gavharafshan, gavharfishon, gavharposh, gavharbop, 
gavharrez, formed with the participation of the wordpearl( gavhar). These words have been used in many places in the figurative sense to say beautifuldeeply meaningful words. In the following speech passage, the compound word gavharposh means a word that bring deeply meaningful words, like eloquent:

"Qalam vasfida bir necha qalam surmak va ul raqamkash ta'rifin raqamga kelturmakki, nazm kishvari savodin yakqalam qilib erdi va "Panj ganj" avroqig'a gavharposh raqami tortilib erdi va ul Roqim bobida hamki muning xatti ma'nisin raqam-baraqam bildi, balki qalambaqalam naql qildi. ("Farhod and Shirin")

The combination of gavhar fishon used in Chapter XIII of Hayratul-abror, dedicated to the hymn of Abdurahman Jami, has the figurative meaning of "pouring pearls(gavhar yog'diruvchi), pouring pearls(gavhar to'kuvchi):

Ul ikkisidin biri gavharfishon,

Gavharida nuri yaqindan nishon.

In the following passage from Lisonut-tayr, Alisher Navoi skillfully uses mineralogical terms to describe the attributes of our Prophet Muhammad (s.a.v.) and creates a unique example of metaphor:

Zoti olam durjida durri samin,

Balki Haqdin Rahmatan lil olamin.

To the poet, his essence is pure in the box of the universe, but it is the mercy of Allah sent to the world from the Truth.

Necha ming buxti nechukkim charxi dun,

Durru Gavhar hamlidin bori zabun
Even a few thousand camels are unable to carry the pearls in it.

In these verses, Navoi pointed to the essenceof the content of the works ofFarididdin Attar. In a metaphorical depiction like this, we see a tremendous product of skill.

Rokib o'lkim, kelturubdurmen buroq,

Gardi rohing ayla bu firuza toq.

But I have brought you, be a horseman, so that this turquoise dome of the sky may be your way.

It is known that the term turquoise (firuza) means a bluish stone(ko'kimtir rangli tosh). Firuza toq-fig. Sky.

In this case, the lexeme turquoise (firuza)in a figurative sense, that is, blue, meant the color of the air and served to metaphorically represent the image of the sky:

Ilm daryosi viloyat gavhari,

Olam ahlida ajoyib mazhari.

He was a river of knowledge and a pearl ofguardianship, a unique man among the people of the world.

In this example from Lisonut-tayr, Ali (r.a.) also skillfully used the lexeme of pearl to create the art of metaphor.

We have seen in the example of the ambiguous terms of mineralogy used in the works of the great master of words Alisher Navoi that the same linguistic instrument performs a completely different function in the scientific style and in the literary work. When thinking about the use of words in a literary text, we realized even more deeply that we need to pay attention to both the 
specific styles of literary language and the specific features of the work of art.

\section{CONCLUSION}

It is obvious that mineralogical terms, like other linguistic means, play a special role in enhancing the artistic value of prose and poetry. While these terms serve as a rich source for Uzbek historical lexicology and methodology, they require in-depth research. In this small study, we have tried to illustrate some aspects of the problem, that is, the use of mineralogical terms in the works of Alisher Navoi in a figurative sense, which served as a means of artistic expression.

\section{REFERENCES}

1. Doniyorov $X$. Alisher Navoi and Uzbek literary language. - Tashkent: Ghafur Ghulam. 1972. - p.3

2. Jumayevna Y. N. Linguo culture logical features of metaphors in children's literature (On the example of khudayberditokhtabayev's creative work) /IACADEMICIA: An International Multidisciplinary Research Journal. 2019. - T. 9. - №. 4. - p. 139-145.

3. Danilenko V.P. Linguistic requirements for standardized terminology // Terminology and Norm. - M., 1972 .-- p. 11.

4. Navoiy asarlari lufati. - T .: F.Fulom, 1972 .- p. 154.

5. Alisher Navoiy. Farhod and Shirin. Toshkent: Gafur Gulom. 2006.-p.19.

6. Ikromova. Gulhida. A. (2020). Developing the speech of primary school pupils through the folklore. ACADEMICIA: An International Multidisciplinary Research Journal, 10(5), 567-571.

7. Ярашова, Н. Ж. (2019). ПРОЯВЛЕНИЕ ИНТОНАЦИИ У ДЕТЕЙ ПОСРЕДСТВОМ
ОБРАЩЕНИЯ. In ТРаДИциИ И новациИ В профессиональной подготовке и деятельности педагога (рр. 128-130).

8. Jumaevna, Y. N. (2020). Occupation of the child's personal mental status in dialogual speech. Asian Journal of Multidimensional Research (AJMR), 9(5), 405-408.

9. Yusupovich, K. S. (2020). The Emergence Of Religious Views Is Exemplified By The Southern Regions. The American Journal of Social Science and Education Innovations, 2(10), 143-145. 